\title{
NOTES
}

\section{A New Inhibitor of Melanogenesis, Albocycline K3, Produced by Streptomyces sp. OH-3984}

\author{
Satoshi Takamatsu, Yong-Pil Kim, \\ Masahiko Hayashi, Kanki Komiyama, \\ Genji Imokawa ${ }^{\dagger}$ and Satoshi ŌMUra* \\ The Kitasato Institute, \\ 5-9-1 Shirokane, Minato-ku, Tokyo 108, Japan \\ ${ }^{\dagger}$ Kao Corporation, Biological Science Laboratories, \\ 2606 Akabane, Ichikaimachi, Haga, Tochigi 321-34, Japan
}

(Received for publication December 20, 1995)

In our continuing a search for melanogenesis inhibitors of microbial origin, we have reported albocyclines K1 and K2, which were produced by Streptomyces sp. $\mathrm{OH}-3984^{1,2)}$. The absolute configuration of both compounds was clarified by chemical conversion ${ }^{3)}$. A further study of the strain led to discovery of another macrocyclic compound named albocycline K3 (1) (Fig. 1). This paper describes the isolation, physicochemical properties, structure determination and biological characteristics of $\mathbf{1}$.

The fermentation and isolation of $\mathbf{1}$ were carried out in the same way as reported previously ${ }^{1}$. A stock culture of the producing organism was inoculated into a test tube (i.d. $2 \times 20 \mathrm{~cm}$ ) containing $10 \mathrm{ml}$ of seed medium consisting of $2 \%$ glucose, $0.5 \%$ peptone, $0.3 \%$ dry yeast, $0.5 \%$ meat extract, $0.5 \% \mathrm{NaCl}$ and $0.3 \% \mathrm{CaCO}_{3}(\mathrm{pH}$ 7.0 before sterilization). The tube was incubated at $27^{\circ} \mathrm{C}$ for 72 hours on a reciprocal shaker. Then, $2 \mathrm{ml}$ portions of the culture were transferred to a $500-\mathrm{ml}$ Erlenmeyer flask containing $100 \mathrm{ml}$ of the seed medium. The flask was incubated at $27^{\circ} \mathrm{C}$ for 48 hours on a rotary shaker $(210 \mathrm{rpm})$, and $400 \mathrm{ml}$ of the resulting culture was transferred into a 50-liter fermenter containing 30 liters of the same medium as described above. The fermentation was carried out at $27^{\circ} \mathrm{C}$ for 96 hours of an agitation rate of $160 \mathrm{rpm}$ and an aeration rate of 60 liters per minute.

The fermentation broth of Streptomyces sp. OH-3984 (30 liters) was extracted with EtOAc (25 liters), and the EtOAc layer was dried over anhydrous $\mathrm{Na}_{2} \mathrm{SO}_{4}$ and

Fig. 1. Structure of 1.

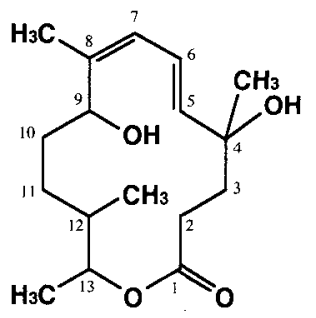

concentrated in vacuo to yield a brown syrup $(10.0 \mathrm{~g})$. The ethyl acetate extracts were chromatographed on a silica gel $(70 \sim 230$ mesh; i.d. $5 \times 36 \mathrm{~cm})$ column using $\mathrm{CHCl}_{3}$-acetone $(8: 2)$. Finally, isolation of the active fraction by preparative HPLC (Cosmosil 5C18-AR packed column, i. d. $20 \times 250 \mathrm{~mm}$, Nacalai Tesque) using a solvent system of $\mathrm{MeOH}-\mathrm{H}_{2} \mathrm{O}(80: 20)$ gave $1(33 \mathrm{mg})$ and albocycline $(800 \mathrm{mg})$, respectively.

The physicochemical properties of $\mathbf{1}$ are summarized in Table 1. The molecular formula of 1 was determined as $\mathrm{C}_{17} \mathrm{H}_{28} \mathrm{O}_{4}$ by $\mathrm{HR}$ positive-FAB mass analysis. The IR absorption at $1770 \mathrm{~cm}^{-1}$ of 1 showed the presence of a lactone group. Acetylation of 1 with acetic anhydride in pyridine at room temperature gave the diacetate of $\mathbf{1}$, which showed that 1 has two hydroxy groups in the molecule. The ${ }^{13} \mathrm{C}$ NMR spectrum of 1 showed 17 carbon signals and the DEPT spectrum of 1 indicated the presence of four methyl, four methylene, six methine and three tertiary carbon signals. In the ${ }^{1} \mathrm{H}$ NMR spectrum of $\mathbf{1}$, two tertiary methyl signals observed at $\delta 0.83(3 \mathrm{H}$, $\mathrm{d}, J=5.9 \mathrm{~Hz}, 12 \mathrm{Me})$ and $\delta 1.20(3 \mathrm{H}, \mathrm{d}, J=6.3 \mathrm{~Hz}, 13 \mathrm{Me})$ were characteristic of derivatives of the albocyclines ${ }^{4)}$. Furthermore, the ${ }^{13} \mathrm{C}$ and ${ }^{1} \mathrm{H}$ NMR chemical shifts between $\mathrm{C}-1$ and $\mathrm{C}-5$ were similar to those of 2,3dihydroalbocycline ${ }^{2)}$. However, the signal of the methoxy group, a characteristic functional group of albocycline, was not observed. In the ${ }^{1} \mathrm{H}-{ }^{1} \mathrm{H}$ COSY spectrum of $\mathbf{1}$, the connection from $\mathrm{C}-5$ to $\mathrm{C}-13$ via a long range coupling between $\mathrm{H}-7(\delta 6.09)$ and $\mathrm{H}-9(\delta 3.70)$ was demonstrated. Final confirmation of structure 1 was undertaken using HMBC experiments $(J=8 \mathrm{~Hz})$ summarized in Table 2. These results clearly indicated that the structure is the derivative of albocycline without a methoxy group as shown in the Fig. 1. Although this structure is similar to that of cineromycin $\mathrm{B}^{5}$, a 14 -membered macrocyclic compound without a methoxy group, the physicochemical and biological properties of 1 are different from those of cineromycin B. Cineromycin B was reported as a

Table 1. Physicochemical data of $\mathbf{1 .}$

\begin{tabular}{|c|c|}
\hline Appearance & Colorless oil \\
\hline$[\boldsymbol{\alpha}]_{D} 24$ & $-10.0^{\circ}($ c. $0.4, \mathrm{MeOH})$ \\
\hline Molecular formula & $\mathrm{C}_{17} \mathrm{H}_{28} \mathrm{O}_{4}$ \\
\hline UV $\lambda_{\max }{ }^{\mathrm{MeOH}} \mathrm{nm}$ & End absorption \\
\hline $\mathrm{IR} v_{\max } \mathrm{KBr}^{\mathrm{KBr}} \mathrm{cm}^{-1}$ & $3448,2927,1770,1365$ \\
\hline Pos. FAB-MS $(\mathrm{m} / \mathrm{z})$ & $297(\mathrm{M}+\mathrm{H})^{+}$ \\
\hline HR Pos. FAB-MS $(m / z)$ & Obsd. $319.0768\left(\mathrm{C}_{17} \mathrm{H}_{28} \mathrm{O}_{4} \mathrm{Na}\right)$ \\
\hline & Calcd. 319.0753 \\
\hline Color reaction & . \\
\hline Positive & $50 \% \mathrm{H}_{2} \mathrm{SO}_{4}+\Delta$, lodine \\
\hline Negative & $\begin{array}{l}\text { Dragendorff's reagent; Ehrlich's reagent }+\Delta \\
\text { Ninhydrin reagent }\end{array}$ \\
\hline
\end{tabular}


Table 2. ${ }^{13} \mathrm{C}$ NMR, ${ }^{1} \mathrm{H}$ NMR and $\mathrm{HMBC}(J=8 \mathrm{~Hz})$ data of 1 in $\mathrm{CDCl}_{3}$.

\begin{tabular}{|c|c|c|c|c|}
\hline No. & ${ }^{13} \mathrm{C}$ & $\mathbf{M}$ & l $\mathrm{H}(\mathrm{M}, J$ value in $\mathrm{Hz})$ & $\mathrm{HMBC}\left({ }^{1} \mathrm{H} \rightarrow{ }^{13} \mathrm{C}\right)$ \\
\hline 1. & 176.8 & $s$ & & \\
\hline 2. & 28.9 & $t$ & $2.56(2 \mathrm{H}, \mathrm{m})$ & $\mathrm{C}-1, \mathrm{C}-3, \mathrm{C}-4$ \\
\hline 3. & 34.5 & $t$ & $2.18,2.09(1 \mathrm{H}, \mathrm{m}, \mathrm{each})$ & $\mathrm{C}-1, \mathrm{C}-2, \mathrm{C}-4,4-\mathrm{Me}, \mathrm{C}-5$ \\
\hline 4. & 85.6 & $s$ & & \\
\hline 5. & 134.1 & $d$ & $5.69(1 \mathrm{H}, \mathrm{d}, J=15.2)$ & $\mathrm{C}-3, \mathrm{C}-4,4-\mathrm{Me}, \mathrm{C}-6, \mathrm{C}-7$ \\
\hline 6. & 124.8 & $d$ & $6.48(1 \mathrm{H}, \mathrm{dd}, J=15.2,10.9)$ & $\mathrm{C}-4, \mathrm{C}-5, \mathrm{C}-7, \mathrm{C}-8$ \\
\hline 7. & 122.6 & $d$ & $6.09(1 \mathrm{H}$, br.d, $J=10.9)$ & $\mathrm{C}-5, \mathrm{C}-6, \mathrm{C}-8,8-\mathrm{Me}, \mathrm{C}-9$ \\
\hline 8. & 140.9 & $s$ & & \\
\hline 9. & 81.8 & $d$ & $3.70(1 \mathrm{H}$, br.d, $J=10.9)$ & $\mathrm{C}-8,8-\mathrm{Me}, \mathrm{C}-10, \mathrm{C}-11$ \\
\hline 10. & 30.9 & $t$ & $1.66(2 \mathrm{H}, \mathrm{m})$ & $\mathrm{C}-8, \mathrm{C}-9, \mathrm{C}-11, \mathrm{C}-12$ \\
\hline 11. & 32.9 & $t$ & $1.79(1 \mathrm{H}, \mathrm{m}), 1.26(1 \mathrm{H}, \mathrm{m})$ & $\mathrm{C}-9, \mathrm{C}-10, \mathrm{C}-12,12-\mathrm{Me}, \mathrm{C}-13$ \\
\hline 12. & 37.1 & $d$ & $1.29(1 \mathrm{H}, \mathrm{m})$ & $\mathrm{C}-11,12-\mathrm{Me}, \mathrm{C}-13,13-\mathrm{Me}$ \\
\hline 13. & 79.8 & $d$ & $3.11(1 \mathrm{H}, \mathrm{m})$ & $\mathrm{C}-1, \mathrm{C}-11, \mathrm{C}-12,12-\mathrm{Me}, 13-\mathrm{Me}$ \\
\hline 4-Me & 26.8 & $q$ & $1.52(3 \mathrm{H}, \mathrm{s})$ & $\mathrm{C}-3, \mathrm{C}-4, \mathrm{C}-5$ \\
\hline 8-Me & 13.9 & $q$ & $1.77(3 \mathrm{H}, \mathrm{s})$ & $\mathrm{C}-7, \mathrm{C}-8, \mathrm{C}-9$ \\
\hline 12-Me & 17.9 & $q$ & $0.83(3 \mathrm{H}, \mathrm{d}, J=5.9)$ & $\mathrm{C}-11, \mathrm{C}-12, \mathrm{C}-13$ \\
\hline 13-Me & 19.7 & $q$ & $1.20(3 \mathrm{H}, \mathrm{d}, J=6.3)$ & C- $-12, \mathrm{C}-13$ \\
\hline
\end{tabular}

de- $O$-methoxy-derivative of albocycline which showed the following properties: a neutral colorless plate, $\mathrm{mp}$ $149 \sim 150^{\circ} \mathrm{C},[\alpha]_{\mathrm{D}}^{24}-110^{\circ}(c 1.0, \mathrm{MeOH})$, molecular formula $\left(\mathrm{C}_{17} \mathrm{H}_{26} \mathrm{O}_{4}\right)$, molecular weight (294) and antibacterial activity, however, the structure of cineromycin B was not clearly elucidated ${ }^{6}$.

Albocycline K3 (1) inhibited the melanogenesis of B16 melanoma cells at a concentration of $15.0 \mu \mathrm{g} / \mathrm{ml}$ without cytotoxicity using the previously described method ${ }^{1)}$. Albocycline K3 (1) showed no antimicrobial activity against Gram-positive and Gram-negative bacteria, fungi or yeast at a concentration of $1.0 \mathrm{mg} / \mathrm{ml}$ in the paper disc method reported previously ${ }^{7)}$. Recently, the search for new melanin biosynthesis inhibitors of microbial origin has been performed using some unique screening methods, and isonitrile antibiotics, trichoviridin ${ }^{8)}$ and MR304A ${ }^{9)}$ were reported to inhibit not only melanogenesis but also mushroom tyrosinase. However, the mechanism of action of $\mathbf{1}$ is unknown since no inhibition of tyrosinase activity was observed by the method of AKIU et al. ${ }^{10)}$ and POMERANTZ et al. ${ }^{11}$. Therefore, it is of interest to examine the mechanism of the inhibitory effect of albocycline K3 (1) on melanogenesis.

\section{Acknowledgments}

This work was supported in part by funds from the Japan Keirin Association.

\section{References}

1) Komiyama, K.; S. Takamatsu, Y. TaKahashi, M. Shinose, M. Hayashi, H. Tanaka, Y. Iwal, S. Ömura \& G. IмоKAWA: New inhibitors of melanogenesis, OH-3984 K1 and K2: I. Taxonomy, fermentation, isolation and biological characteristics. J. Antibiotics 46: $1520 \sim 1525,1993$

2) Takamatsu, S.; M.-C. Rho, M. Hayashi, K. Komiyama, H. Tanaka, S. OMura \& G. Imokawa: New inhibitors of melanogenesis, OH-3984 K1 and K2: II. Physicochemical properties and structural elucidation. J. Antibiotics 46: 1526 1529, 1993

3) Sunazuka, T.; R. Obata, Z. Li, S. Takamatsu, K. Komryama, S. OMmura \& A. B. SMith, III: Relative and absolute stereochemistry of the melanogenesis inhibitors, $\mathrm{OH}-3984 \mathrm{~K} 1$ and K2. Partial synthesis from albocycline. Tetrahedron Letters 35: 2635 2636, 1995

4) Harada, K.; F. Nishida, H. Takagi, M. Suzuki \& T. IWASHITA: Studies on an antibiotic, albocycline VII. Minor components of albocycline. J. Antibiotics 37: $1187 \sim 1197,1984$

5) Dictionary of Antibiotics and related substance. $E d s$., B. W. Bycroft, pp. 24, Chapman and Hall, 1988

6) Miyairi, N.; M. Takashima, K. Shimizu \& H. Sakai: Studies on new antibiotics, cineromycins $\mathrm{A}$ and B. J. Antibiotics, Ser. A 19:56 62, 1966

7) Komiyama, K.; S. Takamatsu, Y.-P. Kim, A. MatsuMOTO, Y. TAKahashi, M. Hayashi, H. B. WoOdRUfF \& S. ŌMURA: Louisianins A, B, C and D: non-steroidal growth inhibitors of testosterone-responsive SC 115 cells. I. Taxonomy, fermentation, isolation and biological characteristics. J. Antibiotics 48: 1086 1089, 1995

8) Hashimoto, R.; S. Takahashi, K. Hamano, T. Mori \& A. Nakagawa: New method for screening the melanin biosynthesis inhibitor by using the larval haemolymph of the silkworm, Bombyx mori, and the inhibitory activity of trichoviridin. Biosci. Biotech. Biochem. 58: 1725 1726,1994

9) Lee, C. H.; H. Koshino, M. C. Chung, H. J. LeE \& Y. H. Kно: MR304A, a new melanin synthesis inhibitor produced by Trichoderma harzianum. J. Antibiotics 48: $1168 \sim 1170,1995$

10) Akiu, S.; Y. Suzuki, T. Asahara, Y. Fujinuma \& M. FUKUDA: Inhibitory effect of arbutin on melanogenesis-Biochemical study using cultured B16 melanoma cells - . Jpn. J. Dermatol. 101: 609 613, 1991

11) Pomerantz, S. H.: Separation, purification and properties of two tyrosinases from hamster melanoma. J. Biol. Chem. 238: $2351 \sim 2357,1963$ 